\title{
Transformasi Paradigma Dan Proses Dalam Konteks Penyelenggaraan Pemerintahan Daerah Berbasis Elektronik
}

\author{
Perdin Pardamean Lubis*
}

\begin{abstract}
Abstrak
Memanfaatkan Teknologi Informasi dan Komunikasi(TIK) untuk memberikan layanan kepada pengguna layanan berbasis elektronik. Hal ini berdasarkan Peraturan Presiden Nomor 95 Tahun 2018 tentang Sistem Pemerintahan Berbasis Elektronik (SPBE). Seluruh pemerintah Daerah wajib menerapkan SPBE atau yang lebih dikenal dengan E-Government. Rumusan masalah bagaimana transformasi paradigma dan proses dalam konteks penyelenggaraan pemerintahan daerah berbasis elektronik? Tujuan menganalisa transformasi paradigma dan proses dalam konteks penyelenggaraan pemerintahan daerah berbasis elektronik. Kegunaan dapat menambah wawasan mengenai penyelenggaraan pemerintahan daerah berbasis elektronik. Metode penelitian yan digunakan yuridis normatif. Hasil melakukan transformasi paradigma dan proses pemerintahan dengan melakukan integrasi layanan perencanaan, layanan penganggaran, layanan pengadaan, dan layanan manajemen kinerja yang berbasis elektronik. Kesimpulan penerapan SPBE telah dihasilkan oleh Pemerintah Daerah dengan memberi kontribusi efisiensi dan efektivitas penyelenggaraan pemerintahan meskipun masih beragaman.
\end{abstract}

Kata Kunci: Transformasi, Paradigma dan Proses, Pemerintahan Daerah, SPBE.

\section{Paradigm Transformation and Process in the Context of Organizing Electronic-Based Regional Government}

\begin{abstract}
Utilizing Information and Communication Technology (ICT) to provide services to users of electronic-based services. This is based on Presidential Regulation Number 95 of 2018 concerning Electronic-Based Government Systems (SPBE). All regional governments must implement SPBE or better known as E-Government. The formulation of the problem how is the transformation of paradigms and processes in the context of the implementation of electronic-based local government? The purpose of analyzing the transformation of paradigms and processes in the context of the implementation of electronic-based local government. Usability can add insight on the implementation of electronic-based local government. The research method used is normative juridical. The results of transforming the paradigm and governance process by integrating planning services, budgeting services, procurement services, and electronic-based performance management services. The conclusion of the application of the
\end{abstract}

*E-mail: perdinlubis241@ gmail.com 
SPBE has been produced by the Regional Government by contributing to the efficiency and effectiveness of the administration of government, although it is still diverse.

Keywords: Transformation, Paradigm and Process, Local Government, SPBE

\section{Pendahuluan}

Istilah transformasi merujuk kepada aktivitas untuk mengubah sesuatu, baik komposisi, struktur maupun karakternya. Tranformasi paradigma dan proses dalam konteks penyelenggaraan Pemerintahan Daerah berbasis elektronik berkaitan dengan upaya inovatif Pemerintah Daerah untuk memanfaatkan revolusi Teknologi Informasi dan Komunikasi (TIK)dalam rangka mewujudkan penyelenggaraan pemerintahan yang terbuka, partisipatif, inovatif, dan akuntabel, serta peningkatan kolaborasi antar instansi Pemerintah Daerah dalam melaksanakan urusan dan tugas pemerintahan untuk mencapai tujuan bersama, meningkatkan kualitas dan jangkauan pelayanan publik kepada masyarakat luas, dan menekan tingkat penyalahgunaan kewenangan dalam bentuk kolusi, korupsi, dan nepotisme.

Upaya untuk mendorong penerapan Sistem Pemerintahan Berbasis Elektronik (SPBE) telah banyak dilakukan oleh pemerintah dengan menerbitkan peraturan perundang-undangan yang mengamanatkanperlunya penyelenggaraan berbasis elektronik, yaitu misalnya dengan adanyaUndang-Undang 14 Tahun 2008 Tentang Keterbukaan Informasi Publik, Undang-undang Nomor 25 Tahun 2009 tentang Pelayanan Publik, Undang-Undang Nomor 5 Tahun 2014 tentang Aparatur Sipil Negara, Undang-Undang Nomor 23 Tahun 2014sebagaimana telah beberapa kalidiubah terakhir dengan Undang-Undang Nomor 9 Tahun 2015tentang Perubahan Kedua Undang-Undang Nomor 23 Tahun 2014 tentang Pemerintahan Daerah, Undang-Undang Nomor 30 Tahun 2014 tentang Administrasi Pemerintahan, Undang-Undang Nomor 19 Tahun 2016 Tentang Perubahan Atas Undang-Undang Nomor 11 tahun 2008 Informasi Dan Transaksi Elektronik, Peraturan Pemerintah Nomor 18 Tahun 2016 tentang Perangkat Daerah, Peraturan Presiden Nomor 81 Tahun 2010 tentang Grand Design Reformasi Birokrasi 2010-2025, Peraturan Presiden Nomor 95 Tahun 
2018 tentang Sistem Pemerintahan Berbasis Elektronik, Instruksi Presiden Nomor 9 Tahun 2015 tentang Pengelolaan Komunikasi Publik, Instruksi Presiden Republik Indonesia Nomor 3 Tahun 2003 tentang Kebijakan dan Strategi Pengembangan E-Government, Peraturan Menteri Aparatur Negara Nomor 83 Tahun 2012 tentang Pedoman Pemanfaatan Media Sosial Instansi Pemerintahan, dan Peraturan Menteri Komunikasi dan Informatika Nomor 14 Tahun 2016 Tentang Pedoman Nomenklatur Perangkat Daerah Bidang Komunikasi dan Informatika.

Berbagai penerapan SPBE telah dihasilkan oleh Instansi Pusat dan Pemerintah Daerah dan memberi kontribusi elisiensi dan efektivitas penyelenggaraan pemerintahan. Namun demikian, hasil pengembangan SPBE dan tingkat maturitasnya masih sangat beragam antar Instansi Pusat dan Pemerintah Daerah. Berdasarkan hasil Pemeringkatan E-Government Indonesia (PeGI) tahun 2015, rata-rata capaian penerapan SPBE pada Instansi Pusat mencapai nilai indeks 2,7 (baik), sedangkan Pemerintah Daerah mencapai nilai indeks 2,5 (kurang). Hal ini mengindikasikan adanya permasalahanpermasalahan dalam pengembangan SPBE secara nasional. Permasalahan tersebut diantaranyabelum adanya Tata Kelola SPBE yang terpadu secara nasional, SPBE belum diterapkan pada penyelenggaraan administrasi pemerintahan dan pelayanan publik, jangkauan infrastruktur TIK ke seluruh wilayah dan ke semua lapisan masyarakat yang belum optimal, danketerbatasan jumlah ASN yang memiliki kompetensi teknis TIK. (Lampiran Peraturan Presiden Nomor 95 Tahun 2018 tentang Sistem Pemerintahan Berbasis Elektronik)

Pada titik inilah, Pemerintah Daerah diharapkan melakukan transformasi paradigma dan proses dalam konteks penyelenggaraan Pemerintahan Daerah berbasis elektronik. Transformasi paradigma dan proses tersebut tentunya akan menciptakan proses pemerintahan yang terintegrasi antara Instansi Pusat dan Pemerintah Daerah sehingga terbentuk satu kesatuan pemerintahan yang utuh dan menyeluruh serta menghasilkan birokrasi pemerintahan danpelayanan publik yang berkinerja tinggi. 


\section{Pembahasan}

\section{A. Konsep Pemerintahan Daerah}

Konstruksi penyelenggaraan pemerintah daerah dan otonomi daerah di Indonesia pada dasarnya diatur dalam Undang-Undang Dasar 1945 di Bab VI Pasal 18, 18A dan 18 B, yang selengkapnya berbunyi sebagai berikut:

Pasal 18:

(1) Negara Kesatuan Republik Indonesia dibagi atas daerah-daerah provinsi dan daerah provinsi itu dibagi atas kabupaten dan kota, yang tiap-tiap provinsi, kabupaten, dan kota itu mempunyai pemerintahan daerah, yang diatur dengan undang-undang.

(2) Pemerintahan daerah provinsi, daerahkabupaten, dan kota mengatur dan mengurussendiri urusan pemerintahan menurutasas otonomi dan tugas pembantuan.

(3) Pemerintahan daerah provinsi, daerah kabupaten, dan kota memiliki Dewan Perwakilan Rakyat Daerah yang anggota-anggotanya dipilih melalui pemilihan umum.

(4) Gubernur, Bupati, dan Walikota masing-masing sebagai kepala pemerintah daerah provinsi, kabupaten, dan kota dipilih secara demokratis.

(5) Pemerintahan daerah menjalankan otonomi seluas-luasnya, kecuali urusan pemerintahan yang oleh undang-undang ditentukan sebagai urusan Pemerintah Pusat.

(6) Pemerintahan daerah berhak menetapkan peraturan daerah dan peraturanperaturan lain untuk melaksanakan otonomi dan tugas pembantuan.

(7) Susunan dan tata cara penyelenggaraan pemerintahan daerah diatur dalam undang-undang.

Pasal 18A:

(1) Hubungan wewenang antara pemerintah pusat dan pemerintahan daerah provinsi, kabupaten, dan kota, atau antara provinsi dan kabupaten dan kota, diatur dengan undang-undang dengan memperhatikan kekhususan dan keragaman daerah. 
(2) Hubungan keuangan, pelayanan umum, pemanfaatan sumber daya alam dan sumber daya lainnya antara pemerintah pusat dan pemerintahan daerah diatur dan dilaksanakan secara adil dan selaras berdasarkan undang-undang.

Pasal 18B:

(1) Negara mengakui dan menghormati satuan-satuan pemerintahan daerah yangbersifat khusus atau bersifat istimewayang diatur dengan undangundang.

(2) Negara mengakui dan menghormati kesatuan-kesatuan masyarakat hukum adatbeserta hak-hak tradisionalnya sepanjangmasih hidup dan sesuai dengan perkembanganmasyarakat dan prinsip NegaraKesatuan Republik Indonesia, yang diaturdalam undang-undang.

Pemberian otonomi yang seluas-seluasnya kepada Daerah dilaksanakan berdasarkan prinsip negara kesatuan. Dalam negara kesatuan kedaulatan hanya ada pada pemerintahan negara atau pemerintahan nasional dan tidak ada kedaulatan pada Daerah. Oleh karena itu, seluas apa pun otonomi yang diberikan kepada Daerah, tanggung jawab akhir penyelenggaraan Pemerintahan Daerah akan tetap ada ditangan Pemerintah Pusat. Untuk itu Pemerintahan Daerah pada negara kesatuan merupakan satu kesatuan dengan Pemerintahan Nasional. Sejalan dengan itu, kebijakan yang dibuat dan dilaksanakan oleh Daerah merupakan bagian integral dari kebijakan nasional. Pembedanya adalah terletak pada bagaimana memanfaatkan kearifan, potensi, inovasi, daya saing, dan kreativitas Daerah untuk mencapai tujuan nasional tersebut di tingkat lokal yang pada gilirannya akan mendukung pencapaian tujuan nasional secara keseluruhan. (Penjelasan Atas Undang-Undang Republik Indonesia Nomor 23 Tahun 2014 Tentang Pemerintahan Daerah)

Berbeda dengan penyelenggaraan pemerintahan di pusat yang terdiri atas lembaga eksekutif, legislatif, dan yudikatif, penyelenggaraan Pemerintahan Daerah dilaksanakan oleh DPRD dan kepala daerah. DPRD dan kepala daerah berkedudukan sebagai unsur penyelenggara pemerintahan daerah yang diberi 
mandat rakyat untuk melaksanakan Urusan Pemerintahan yang diserahkan kepada Daerah. Dengan demikian maka DPRD dan kepala daerah berkedudukan sebagai mitra sejajar yang mempunyai fungsi yang berbeda. DPRD mempunyai fungsi pembentukan Perda, anggaran dan pengawasan, sedangkan kepala daerah melaksanakan fungsi pelaksanaan atas Perda dan kebijakan Daerah. Dalam mengatur dan mengurus Urusan Pemerintahan yang menjadi kewenangan Daerah tersebut, DPRD dan kepala daerah dibantu oleh Perangkat Daerah. Sebagai konsekuensi posisi DPRD sebagai unsur penyelenggaraPemerintahan Daerah maka susunan, kedudukan, peran, hak,kewajiban, tugas, wewenang, dan fungsi DPRD tidak diatur dalambeberapa undang-undang namun cukup diatur dalam Undang-Undangini secara keseluruhan guna memudahkan pengaturannya secaraterintegrasi. (Penjelasan Atas Undang-Undang Republik Indonesia Nomor 23 Tahun 2014 Tentang Pemerintahan Daerah)

Penyelenggara Pemerintahan Daerahterdiri atas kepala daerah dan DPRD dibantu oleh perangkat daerah. Penyelenggara Pemerintahan Daerah berpedoman pada asas penyelenggaraan pemerintahan negara yang terdiri atas: kepastian hukum, tertib penyelenggara negara, kepentingan umum, keterbukaan, proporsionalitas, profesionalitas, akuntabilitas, efisiensi, efektivitas, dan keadilan. (Pasal 57 dan 58 Undang-undang Pemerintahan Daerah).

Kepala Daerah baik itu Gubernur maupun Bupati/Walikota mempunyai tugas sebagai berikut:

a. memimpin pelaksanaan Urusan Pemerintahan yang menjadi kewenangan Daerah berdasarkan ketentuan peraturan perundang-undangan dan kebijakan yang ditetapkan bersama DPRD;

b. memelihara ketenteraman dan ketertiban masyarakat;

c. menyusun dan mengajukan rancangan Perda tentang RPJPD dan rancangan Perda tentang RPJMD kepada DPRD untuk dibahas bersama DPRD, serta menyusun dan menetapkan RKPD;

d. menyusun dan mengajukan rancangan Perda tentang APBD, rancangan Perda tentang perubahan APBD, dan rancangan Perda tentang 
pertanggungjawaban pelaksanaan APBD kepada DPRD untuk dibahas bersama;

e. mewakili Daerahnya di dalam dan di luar pengadilan, dandapat menunjuk kuasa hukum untuk mewakilinya sesuaidengan ketentuan peraturan perundangundangan;

f. mengusulkan pengangkatan wakil kepala daerah; dan

g. melaksanakan tugas lain sesuai dengan ketentuan peraturan perundang undangan. (Pasal 65 Undang-undang Pemerintahan Daerah).

Dalam melaksanakan tugas sebagaimana dimaksud di atas, kepala daerah berwenang:

a. mengajukan rancangan Perda;

b. menetapkan Perda yang telah mendapat persetujuan bersama DPRD;

c. menetapkan Perkada dan keputusan kepala daerah

d. mengambil tindakan tertentu dalam keadaan mendesak yangsangat dibutuhkan oleh Daerah dan/atau masyarakat; dan

e. melaksanakan wewenang lain sesuai dengan ketentuan peraturan perundang-undangan. (Pasal 65 Undang-undang Pemerintahan Daerah).

Kepala daerah dalam memimpin penyelenggaraan pemerintahan di daerah dapat dibantu oleh wakil kepala daerah. Wakil kepala daerah untuk Daerah provinsi disebut wakil gubernur, dan untuk Daerah kabupaten disebut wakil bupati, serta untuk Daerah kota disebut wakil wali kota. Wakil Kepala daerah mempunyai tugas: (Pasal 66 Undang-undang Pemerintahan Daerah)

a. membantu kepala daerah dalam:

1) memimpin pelaksanaan Urusan Pemerintahan yang menjadi kewenangan Daerah;

2) mengoordinasikan kegiatan Perangkat Daerah dan menindaklanjuti laporan dan/atau temuan hasil pengawasan aparat pengawasan;

3) memantau dan mengevaluasi penyelenggaraan Pemerintahan Daerah yang dilaksanakan oleh Perangkat Daerah provinsi bagi wakil gubernur; dan 
4) memantau dan mengevaluasi penyelenggaraan pemerintahan yang dilaksanakan oleh Perangkat Daerah kabupaten/kota, kelurahan, dan/atau Desa bagi wakil bupati/wali kota;

b. memberikan saran dan pertimbangan kepada kepala daerah dalam pelaksanaan Pemerintahan Daerah;

c. melaksanakan tugas dan wewenang kepala daerah apabila kepala daerah menjalani masa tahanan atau berhalangan sementara; dan

d. melaksanakan tugas lain sesuai dengan ketentuan peraturanperundangundangan.

DPRD adalah lembaga perwakilan rakyat daerah yang berkedudukan sebagai unsur penyelenggara Pemerintahan Daerah. Dalam kedudukannya sebagai unsur penyelenggara pemerintah daerah, berdasarkan DPRD mempunyai fungsi: (Pasal 149 Undang-undang Pemerintahan Daerah)

a. pembentukan Perda Kabupaten/Kota;

b. anggaran; dan

c. pengawasan.

Tugas dan wewenang DPRD sebagai berikut: (Pasal 154 Ayat (1) Undangundang Pemerintahan Daerah)

a. membentuk Perda Kabupaten/Kota bersama bupati/wali kota;

b. membahas dan memberikan persetujuan rancangan Perda mengenai APBD kabupaten/kota yang diajukan oleh bupati/wali kota;

c. melaksanakan pengawasan terhadap pelaksanaan Perda dan APBD kabu paten/kota;

d. memilih bupati/wali kota;

e. mengusulkan pengangkatan danpemberhentian bupati/wali kota kepada Menteri melalui gubernur sebagai wakil Pemerintah Pusat untuk mendapatkan pengesahan pengangkatan dan pemberhentian.

f. memberikan pendapat dan pertimbangan kepada Pemerintah Daerah kabupaten/kota terhadap rencana perjanjian international di Daerah; 
g. memberikan persetujuan terhadap rencana kerja sama internasional yang dilakukan oleh Pemerintah Daerah kabupaten/kota;

h. meminta laporan keterangan pertanggungjawaban bupati/wali kota dalam penyelenggaraan Pemerintahan Daerah kabupaten/kota;

i. memberikan persetujuan terhadap rencana kerja sama dengan Daerah lain atau dengan pihak ketiga yang membebani masyarakat dan Daerah;

j. melaksanakan tugas dan wewenang lain yang diatur dalam ketentuan peraturan perundang-undangan.

\section{B. Konsep Pemerintahan yang baik (good governance)}

Prinsip good governance dalam proses penyelenggaraan Pemerintahan Daerah merupakan sebuah tuntutan bagi Pemerintah Daerah dalam rangka mewujudkan pemerintahan yang demokratis, bersih, transparan, dapat di pertanggungjawabkan, efektif dan efisien. (Yulia Neta, 2012 : 2). Good Governance mengandung pengertian menjunjung tinggi nilai-nilai dalam kehidupan masyarakat berbangsa dan bernegara dan yang berhubungan dengan kepemimpinan. Good Governance juga merupakan wujud nyata dalam penyelenggaraan Pemerintahan Negara yang bersih atau tata kelola yang baik dan benar. (Jopinus Saragih, $2012: 18$ )

Dalam konsep governance paling dasar, disebut ada tiga stakeholder utama yang saling berinteraksi dan menjalankan fungsinya masing-masing yaitu negara atau pemerintah (state), sektor swasta atau dunia usaha (private sektor) dan masyarakat (society). Institusi pemerintah berfungsi menciptakan lingkungan politik dan hukum yang kondusif, sedangkan sektor swasta menciptakan pekerjaan dan pendapatan, sedangkan masyarakat berperan dalam membangun interaksi sosial, ekonomi dan politik termasuk mengajak kelompok-kelompok masyarakat untuk berpartisipasi dalam aktivitas ekonomi, sosial dan politik. (Hetifah Sj Sumarto, 2004 : 73)

\section{Konsep SPBE}

Pasal 1 angka 1 Peraturan Presiden Nomor 95 Tahun 2018 tentang SPBE menegaskan bahwa SPBE adalah penyelenggaraan pemerintahan yang 
memanfaatkan TIK untuk memberikan layanan kepada Pengguna SPBE. SPBE bukan hanya sekedar penggunaan aplikasi atau sistem informasi dalam pengerjaan operasional kegiatan keseharian pemerintahan. Lebih dari itu, SPBE meliputi beberapa domain antara lain Domain Kegiatan Pemerintahan, TIK serta Layanan. Di domain Kegiatan Pemerintahan ruang lingkup SPBE meliputi Rencana Induk SPBE, Proses Bisnis, Anggaran dan Belanja SPBE serta Data dan Informasi Elektronik. Di Domain TIK, SPBE meliputi Penyediaan Pusat Data Terpadu, Jaringan Intra Pemerintah, Sistem Penghubung Layanan Pemerintah, Aplikasi Layanan SPBE serta Keamanan Informasi Pemerintah. Sementara di Domain Layanan, SPBE meliputi Layanan Administrasi Pemerintahan Berbasis Elektronik dan Layanan Publik Berbasis Elektronik. (https://spbe.menpan.go.id., diakses tanggal 23 November 2019)

Dalam pelaksanaan SPBE dikenal tipe hubungan kerja yang merupakan bagian dari proses bisnis yang harus diperhatikan untuk menjamin tepatnya sasaran kinerja yang dilakukan. Tipe hubungan kerja tersebut adalah: (Jesper Schalaeger, $2013: 8-20$ )

\section{Government to Citizen (G2C)}

Government to Citizen $(G 2 C)$ merupakan teknologi informasi yang mempunyai tujuan untuk memperbaiki hubungan interaksi antara pemerintah dengan masyarakat yang berkaitan dengan transparansi informasi, informasi akuntabilitas kinerja dan rencana kerja sehingga memudahkan masyarakat dalam mendapatkan informasi penting tersebut. Government to Citizen (G2C) adalah penyampaian layanan publik dan informasi satu arah oleh pemerintah ke masyarakat, Memungkinkan pertukaran informasi dan komunikasi antara masyarakat dan pemerintah, contohnya: Pajak online, mencari Pekerjaan, Layanan Jaminan sosial, Dokumen pribadi (Kelahiran dan Akte perkawinan, Aplikasi Paspor, Lisensi Pengarah), Layanan imigrasi, Layanan kesehatan, Beasiswa, penanggulangan bencana. 


\section{Government to Business (G2B)}

Government to Business (G2B)merupakan jenis hubungan pemerintahan dengan bisnis yang terjadi karena kebutuhan relasi antara pemerintah dengan kalangan pelaku bisnis atau sebaliknya dengan tunjuan untuk meningkatkan kemudahan berbisnis terkait regulasi bisnis yang diterapkan pemerintah, permodalan atau kerjasama padat modal juga padat karya. Government to Business (G2B)adalah transaksi-transaksi elektronik dimana pemerintah menyediakan berbagai informasi yang dibutuhkan bagi kalangan bisnis untuk bertransaksi dengan pemerintah.Mengarah kepada pemasaran produk dan jasa ke pemerintah untuk membantu pemerintah menjadi lebih efisien melalui peningkatan proses bisnis dan manajemen data elektronik. Aplikasi yang memfasilitasi interaksi G2B maupun B2G adalah Sistem e-procurement. Contoh : Pajak perseroan, Peluang Bisnis, Pendaftaran perusahaan, peraturan pemerintah (Hukum Bisnis), Pelelangan dan penjualan yang dilaksanakan oleh pemerintah, hak paten merk dagang, dll.

\section{Government to Government (G2G)}

Government to Government $(\mathrm{G} 2 \mathrm{G})$ merupakan sebuah interaksi yang diperuntukkan untuk pertukaran informasi diantara pemerintahan yang berbeda dalam bentuk media elektronik (website, portal) untuk memudahkan memenuhi kebutuhan dalam pencarian informasi antar pemerintahan. Kebutuhan informasi ini berkaitan dengan membangun kerjasama baik ekonomi, militer, politik, sosial, teknologi, lingkungan, sumber daya manusia juga kerja sama hukum. Government to Government (G2G) memungkinkan komunikasi dan pertukaran informasi online antar departemen atau lembaga pemerintahan melalui basis data terintegrasi. Contoh: Konsultasi secara online, blogging untuk kalangan legislatif, pendidikan secara online, pelayanan kepada masyarakat secara terpadu.

\section{Government to Employees (G2E)}

Merupakan hubungan yang dibutuhkan oleh pegawai pemerintahan atau aparatur sipil Negara yang interaksinya dibangun berbasis elektronik 
agar proses bisnis yang dilakukan lebih efektif, efisien dan tepat sasaran sehingga dapat meningkatkan kinerja serta kesejahteraan pegawai.

Secara umum perkembangan SPBE sebagai berikut:

\section{Emergence}

Pada tahap ini dapat dilihat bahwa keseluruhan model memiliki kesamaan konsep yakni menggunakan website sebagai sarana untuk mempublikasikan informasi namun data dan informasi yang dipublikasikan tidak lebih dari sekedar visi, misi, dan aktivitas organisasi pemerintah tersebut. (Michael Margolis and Gerson Moreno-Riano, 2013 : 54). Adapun dalam tahap ini, website masih menjadi sarana komunikasi satu arah dan belum terdapat interaksi secara elektronik antara pemerintah dan masyarakat ataupun adanya tautan yang menghubungkan ke website lembaga pemerintah lainnya. (Euripidis Loukis, Ann Macintosh, and Yannis Charalabidis, $2013: 78-80$ )

\section{Enhance}

Dalam tahap ini, sistem E-Government telah lebih dikembangkan dengan cara memberikan tautan yang menghubungkan dengan informasiinformasi tertentu berupa formulir perizinan, dokumen, laporan, peraturan, atau newsletters (Zaigham Mahmood, 2013 : 360). Adapun publikasi atas informasi melalui elektronik dapat mengurangi jumlah pegawai negeri yang seharusnya melayani masyarakat untuk memberikan informasi tersebut. Untuk tetap menjaga kemutakhiran informasi, masa masing-masing lembaga pemerintah harus memperbaharui informasi minimal 3 (tiga) bulan sekali. (J. Ramon Gil-Garcia, 2012 : 17-18)

\section{Interaksi}

Pada tahap interaksi, halaman situs yang disajikan pemerintah tidak sekedar menyajikan paparan dan informasi mengenai keberadaannya secara online, tetapi juga disertai fasilitas komunikasi secara elektronik (e-mail) sehingga dapat tercipta komunikasi dua arah antara pemerintah dan masyarakat. (Mahmud Akhter Shareef, et.al, 2012 : 95-114) 
Kebanyakan situs yang dibangun oleh pemerintah Indonesia baru memasuki tahap interaksi. Penyajian fasilitas $e$-mail ini dimaksudkan untuk memberikan titik kontak penyaji situs dan pengunjung situs serta memungkinkan pengunjung situs menggali informasi yang lebih mendalam tentang berbagai macam hal yang terkait dengan keberadaan penyaji situs. Dengan adanya halaman situs yang dapat menciptakan komunikasi dua arah seperti ini dapat meningkatkan responsifitas pemerintah terhadap masyarakat. (M. Snellen, M. Thaens, and J.van de Honk, , 2012 : 31-36)

\section{Transaksi}

Pada tahap ini layanan yang diberikan pemerintah melalui halaman situs tidak sebatas informasi mengenai organisasi pemerintah yang bersangkutan secara online dan fasilitas komunikasi melalui e-mail tetapi juga melayani kebutuhan lain dalam 24 (dua puluh empat) jam sepanjang hari seperti pembuatan, perpanjangan, atau pembaharuan perijinan, passport, kartu identitas tertentu atau yang lainnya, beserta pelaksanaan pembayarannya. (Mahmud Akhter Shareef, 2011 : 27-35) Oleh karena itu, tahap ini mensyaratkan validitas situs termasuk keamanannya, terutama keamanan untuk proses approval dari pihak pemerintah. Proses approval harus dipastikan hanya dilakukan oleh pejabat pemerintah yang memang secara struktur memiliki kewenangan untuk melakukannya.

\section{Transformasi/Terintegrasi}

Pada tahap ini, seluruh lembaga pemerintah telah terintegrasi dalam satu halaman situs sehingga suatu halaman situs dapat menjadi one stop service bagi masyarakat serta masyarakat dapat turut berpartisipasi dalam kegiatan pemerintahan dilakukan dengan secara online untuk meningkatkan transparansi, efisiensi, kualitas layanan publik, pengembangan ekonomi dan memberantas korupsi. Lebih lanjut, tahap transformasi ini membutuhkan teknologi yang tinggi, tingkat keamanan yang tinggi serta keterbukaan pihak pemerintah untuk mempublikasikan informasi. 


\section{Transformasi Paradigma dan Proses Penyelenggaraan SPBE}

Tuntutan masyarakat akan terbentuknya kepemerintahan yang bersih, akuntabel dan transparan, mendorong Pemerintah Daerah untuk segera melakukan perubahan terhadap proses pemerintahannya, hal ini demi mewujudkan tata pemerintahan yang baik (good governance). Sebagai salah satu upaya dalam percepatan mewujudkan good governance pemerintah melakukan pengembangan SPBE atau E-Government. E-Government adalah penggunaan teknologi informasi yang dapat meningkatkan hubungan antara pemerintah dan pihak lain yang terkait seperti masyarakat, pelaku bisnis dan instansi pemerintah lain. Adanya pengembangan E-Governmentdapat meningkatkan efisiensi, efektifitas, transparansi dan akuntabilitas dalam penyelenggaraan pemerintahan.

Pemerintahan berbasis elektronik menuntut kualitas pelayanan prima yang tercermin dari: (Sinambela, Lijan P. Rochadi, Sigit. Ghazali, Rusman. Muksin, Akhmad. Setiabudi, Didit. Bima, Djohan. dan Syaifudin, 2006 : 35)

1) Transparansi, yakni pelayanan yang bersifat terbuka, mudah dan dapat di akses oleh semua pihak yang membutuhkan dan disediakan secara memadai serta mudah di mengerti.

2) Akuntabilitas, yakni pelayan yang dapat dipertanggung jawabkan sesuai dengan ketentuan peraturan perundang-undangan.

3) Kondisional, yakni pelayanan yang sesuai dengan kondisi dan kemampuan pemberi dan penerima pelayanan dengan tetap berpegang pada prinsip efesiensi dan efektivitas.

4) Partisipatif, yaitu pelayanan yang dapat mendorong peran serta masyarakat dalam penyelenggaraan pelayanan publik dengan memperhatikan aspirasi, kebutuhan, dan harapan masyarakat.

5) Kesamaan hak, yaitu pelayanan yang tidak melakukan diskriminasi dilihat dari aspek apapun khususnya suku, ras, agama, golongan, status social, dan lain-lain. 
6) Keseimbangan hak dan kewajiban, yaitu pelayanan yang mempertimbangkan aspek keadilan antara pemberi dan penerima pelayanan publik.

Beberapa langkah yang harus ditempuh oleh Pemerintah Daerah dalam rangka mentransformasikan penyelenggaraan pemerintahanberbasis elektronik sebagai berikut:

1) Pemerintah Daerah wajib mengedepankan penerapan birokrasi yang berkinerja tinggi dengan karakteristik integratif, dinamis, transparan, dan inovatif.Birokrasi yang integratif mengutamakan kolaborasi strategis antar instansi pemerintah dan para pemangku kepentingan lainnya untuk berbagi sumber daya dan membangun kekuatan dalam melaksanakan urusan dan tugas pemerintahan. Birokrasi yang dinamis mampu merespon dengan cepat perubahan kondisi lingkungan strategis dengan membangun proses bisnis pemerintahan secara dinamis di dalam maupun antar instansi pemerintah. Birokrasi yang transparan merupakan suatu keharusan untuk membangun kepercayaan dan legitimasi di mata publik. Dengan birokrasi yang transparan pemerintah menunjukkan keseriusannya dalam bekerja untuk kepentingan masyarakat, memahami kebutuhan masyarakat untuk pelayanan publik, serta melakukan pemantauan dan evaluasi kinerja pemerintah. Birokrasi yang inovatif mampu memberikan ruang gerak untuk mengembangkan pelayanan yang lebih cepat, mudah, dan murah sehingga membawa dampak yang besar bagi pertumbuhan ekonomi, pelestarian lingkungan, dan sosial budaya.

2) Pemerintah Daerah membangun pelayanan publik yang terpadu, efektif, responsif, adaptif, dan mudah diakses oleh masyarakat serta memberikan ruang partisipasi masyarakat dalam turut serta penyusunan kebijakan dan program pembangunan. Masyarakat menginginkan kemudahan dalam memperoleh pelayanan dari pemerintah dan tidak disulitkan oleh hubungan birokrasi antar instansi pemerintah. Dengan demikian, Pemerintah Daerah harus membangun integrasi, konsolidasi, dan inovasi Layanan SPBE agar 
mampu memberikan akses layanan mandiri, layanan bergerak, dan layanan cerdas bagi masyarakat.

3) Pemerintah Daerah memanfaatkan TIK yang efektif dan efisien dapat dicapai melalui integrasi infrastruktur, sistem aplikasi, keamanan informasi, dan layanan TIK.

4) SDM di bidang SPBE yang mencakup pegawai ASN dan masyarakat memegang peranan paling penting untuk mewujudkan SPBE yang terpadu dan berkesinambungan. Pegawai ASN di instansi pemerintah memiliki kepemimpinan dan kompetensi teknis SPBE dan masyarakat memitiki tingkat literasi SPBE yang memadai sehingga layanan SPBE dapat diselenggarakan dan dimanfaatkan dengan optimal. Kepemimpinan SPBE diharapkan memiliki karakteristik kolaboratif yaitu kepemimpinan yang meninggalkan ego sektoral dan mendorong penggunaan sumber daya secara bersama di dalam instansi pemerintah dan antar instansi pemerintah untuk mencapai tujuan bersama; daninovatif yaitu kepemimpinan yang mampu mendorong pelaksanaan SPBE berorientasi pada efisiensi, efektivitas, dan manfaat yang bernilai tinggi.

\section{Penutup}

\section{A. Kesimpulan}

Inovasi penerapan TIK dalam bentuk SPBE memberikan peluang untuk mewujudkan arah kebijakan dan strategi dalam rangka menghasilkan sistem pengawasan, sistem administrasi pemerintahan, dan pelayanan publik yang lebih cepat, lebih baik, dan lebih murah. Dan untuk peningkatan transparansi dan akuntabilitas, yang ditandai dengan salah satunya makin efektifnya penerapan E-goverment untuk mendukung manajemen birokrasi secara modern.

\section{B. Saran}

Pemerintahan Daerah, perlu melakukan transformasi paradigma dan proses pemerintahan dengan melakukan integrasi layanan perencanaan, layanan penganggaran, layanan pengadaan, dan layanan manajemen 
kinerja yang berbasis elektronik. Sehingga akan mewujudkan budaya SDM Pegawai ASN yang mampu berfikir kreatif, sistemik, berwawasan global, memiliki etos kerja yang tinggi, mampu mengelola perubahan lingkungan strategis, dan memberikan pelayanan proaktif yang sesuai dengan kebutuhan masyarakat.

\section{Daftar Pustaka}

Gil-Garcia, J. Ramon. Enacting Electronic Government Success: An Integrative Study of Government-wide Websites, Organizational Capabilities, and Institutions. New York: Springer. 2012

Loukis, Euripidis, Ann Macintosh, and Yannis Charalabidis. E-Participation in Souther Europe and The Balkans. New York: Routledge. 2013

Mahmood, Zaigham. E-Government Implementation and Practice in Developing Countries. UnitedStates: Information Science Reference. 2013

Margolis, Michael and Gerson Moreno-Riano, The Prospect of Internet Democracy. England: Ashgate Publishing Limited. 2013

Neta, Yulia. Model Tata Kelola Administrasi Pemerintahan Yang Baik di Daerah Otonom Baru, Fiat Justitia Jurnal Ilmu Hukum, Vol. 6 No. 2. 2012

Saragih, Jopinus. G. Reformasi Aparatur Negara Untuk Melaksanakan Tata Kelola Pemerintahan Yang Baik Dan Benar (Good Governance), Majalah Ilmiah Widya, Vol. 29 No. 319. 2012

Schalaeger, Jesper. E-Government in China:Technology, Power, and Local GovernmentReform. New York: Routledge. 2013

Shareef, Mahmud Akhter. Stakeholder Adoption of E-Government Services: Driving and Resisting Factors. New York: IGI Global Snippet. 2011

Shareef, Mahmud Akhter et.al. Transformational Government Through eGov Practice: Socioeconomic, Cultural, and Technological Issues. United Kingdom: Emerald Group Publishing Limited. 2012

Sinambela, dkk., Reformasi Pelayanan Publik: Teori, Kebijakan, dan Implementasi. Jakarta: Bumi Aksara. 2006 
Snellen, M., M. Thaens, and J.van de Honk. Public Administration in The Information Age: Revisited. Netherlands: IOS Press BV. 2012

Sumarto, Hetifah $\mathrm{Sj}$. Inovasi Partisipasi dan Good Governance. Jakarta: Yayasan Obor Indonesia. 2004

Undang-Undang Nomor 25 Tahun 2009 tentang Pelayanan Publik.

Undang-Undang Nomor 23 Tahun 2014 tentang Pemerintahan Daerah.

Undang-Undang Nomor 30 Tahun 2014 tentang Administrasi Pemerintahan.

Peraturan Presiden Nomor 95 Tahun 2018 tentang Sistem Pemerintahan Berbasis Elektronik.

Instruksi Presiden Nomor 3 Tahun 2003 tentang Kebijakan dan Strategi Pengembangan E-Government.

https://spbe.menpan.go.id., diakses tanggal 23 November 2019, pukul 15.30 WIB 